\title{
Quantity Final Containers Returned
}

National Cancer Institute

\section{Source}

National Cancer Institute. Quantity Final Containers Returned. NCI Thesaurus. Code C106328.

Quantity of final containers returned. 